\title{
Relational Resources Management as Source of Company's Innovativeness and Competitive Advantage
}

\author{
Marta Ziółkowska
}

\begin{abstract}
There exist various resources which an enterprise can use in order to become more innovative and achieve competitive advantage on the market. Relational resources are definitely one of them, for instance enabling a company to make its customers more loyal or to attract new purchasers and other stakeholders. This paper presents the results of a study in which 200 Polish enterprises were asked about what relational resources they used and how frequently. Analysing the results, the authors of the study observed various interesting relationships between the use of relational resources and numerous factors such as the company's development stage, ownership form, turnover, scope of activity and others. The general conclusion drawn is that more and more Polish enterprises tend to use and manage relational resources, but there still exists a visible difference between Poland and West European countries, as far as the extent of this use is concerned. Therefore, the authors of the study recommend a broader approach to the issue, since its development would be profitable from the economic point of view.
\end{abstract}

Index Terms-Relation resources, corporate management, innovativeness, management.

\section{INTRODUCTION}

Relational resources play an essential role in today's economy. They are a source of information and ensure consumers' identification of the company and their certainty that its products will meet their needs. Moreover, relational resources allow internationalisation of enterprises, enabling the ones with recognisable brands to enter new foreign markets faster than their competitors. They also influence benefits perceived by consumers, contributing to their larger satisfaction. They allow companies to create a positive image and a group of loyal customers, which in turn helps to gain and maintain market advantage, since competitive advantage consists in providing purchasers with a greater value added than the competitors. Relational resources, when used competently, contribute in a continuous way to the development of the company, at the same time increasing its value and creating or developing other resources. Polish enterprises can see the need to form inter- and intra-organisational relations, and they have various possibilities of creating and managing them.

Literature suggests the importance of relational resources for innovation [1]-[4]. Considering worldwide economic changes in the last years, one can conjecture that relational resources will indeed play a more and more important role.

Manuscript received June 2, 2013; revised August 5, 2013.

Marta Ziółkowska is with the Institute of Management, Unit of Corporate Management, Warsaw School of Economics, Poland (e-mail: mziolkow@sgh.waw.pl).
Due to the globalisation processes, as well as the competitiveness increase of individual economies, resources such as reputation, brand awareness or relations with companies' environment will condition their growth and development. Therefore, enterprises' activity should focus on identifying and creating their own resources, namely their reputation and image. For the majority of companies, using relational resources is crucial to achieve success and economic growth. The use of appropriate marketing tools is a comprehensive process which requires not only a very high level of sensitivity to customers' needs, but also the knowledge of impact which suitable marketing resources have on them.

Relational resources are resources connected to relations with the enterprise's contractors - suppliers and consumers [5]. They are potential held by the company thanks to its links to the market and customers [6]. Thanks to the enterprise's trademark, its products and services are marked and identified by the customers, which leads to the company gaining the customers' loyalty. Loyalty, in turn, can ensure sales and - in the long run - a good reputation of the company. Also, thanks to the distribution chain, the market of potential customers can be expanded.

In the surveys conducted the respondents were asked about relational resources issues. An attempt was made to analyse the use of relational resources, the implementation of innovative solutions in this field, as well as the contribution of relations management to the enterprises' development. Two research hypotheses were proposed. One of them assumes that the use of modern relational resources management tools in companies is more and more frequent. The other claims that the range of this use varies between enterprises at the stage of growth and development.

\section{Methodology}

The authors of the study began their work with a pilot study on 20 companies. Its objective was to verify the clarity of the questions which the authors intended to ask in the main study and to make any necessary corrections in them. The main empirical study, in turn, was conducted on 200 enterprises belonging to medium and big business entities, due to their bigger scale, greater potential, similar limitations of the resources available, as well as the possibility to use modern resources management tools. It was significant for the purpose of the study to divide the respondents according to their development stage, since the authors of the study assumed that it can influence the attitude and the methods of the company's resources management, as well as particular needs as far as resources and their innovative use are 
concerned. Therefore, it was necessary to divide the enterprises into some entity categories. Apart from the development stage, the respondents were also classified according to other criteria: period of market activity, ownership form, founding capital, scope of activity, domain of activity, number of employees and turnover of the year2012. Thus, it was possible to analyse the respondents' answers in more detail and from various points of view.

Vast majority of the surveyed companies (181 entities) had existed on the market for more than 8 years. This makes the information gathered from them more illuminating. Taking into account these enterprises' maturity and knowledge of the market on which they operate, it can be assumed that the pro-innovative actions undertaken by them result from an adopted strategy, reflect their needs and also some external factors. This assumption seems to be proven by the respondents' self-assessment as far as their development stage is concerned. Almost $60 \%$ (117 entities) stated that they were at the maturity stage and the remaining $41,5 \%$ placed themselves at the growth stage. None of the respondents chose the 'decline stage' answer. More than a half of the research sample consisted of limited liability companies; other ownership forms were hardly represented. Most of the surveyed enterprises (166 entities) had Polish capital, the remaining 34 entities had foreign capital. The criterion of the number of employees gave analogous results: there were 166 medium companies (employing from 50 to 249 persons) and 34 big enterprises (employing 250 persons or more). What is more, the research sample consisted of companies representing various domains of activity, and the authors of the study tried to make this variety well-proportioned to be able to compare representative groups of enterprises operating in the domains of production, trade and service. A similar division could be observed as far as the other criteria scope of activity and turnover of the year 2012 - were concerned. Nevertheless, the most numerous group in the research sample was the one consisting of domestic companies and entities with a turnover from 50 million zlotys to 100 million zlotys (approximately 12 million euro -24 million euro).

\section{RESULTS}

Relations of an enterprise constitute a specific kind of resources. They are relations with customers, suppliers, contractors, business partners, but also competitors and suppliers of complementary goods [7]. Such relations help to create new value by means of synergistic effect and the use of various resources of the company. The current approach towards the customer's role in the enterprise's activity is qualitatively different than the previous ones. It is connected to "closeness to customer models" whose aim is "merging the company and its customers," meaning creating long-lasting mutual relationships, which in turn leads to a situation in which producers produce only the goods which the customers truly need [8].

Another field of research concerned management of those relations. The respondents were asked which relations had been managed in their companies in the years 2009-2012 (Fig.
1). A substantial proportion of respondents answered that those had been relations with purchasers (90.5\%), suppliers/cooperates (88\%) and employees (86,5\%). Nowadays, apart from creating strategies to attract new customers and carry out transactions with them, companies want to retain current customers and build long-lasting relations with them. Demographic changes, slow economic growth, more refined competition, overproduction in some areas - these are the factors due to which there are less new customers today. Therefore, it is more and more expensive to attract them. In fact, winning new customers cost five times more than keeping current ones satisfied. Moreover, managers have realised that losing one customer means much more than losing only one transaction - it also results in losing a whole series of purchases that this particular customer could make if they remained loyal. Although attracting new customers remains an important marketing task, companies' focus is now shifting towards retaining current customers and building long-lasting and profitable relations with them. The key to achieving these goals is the customer's satisfaction and their highest assessment of the enterprise [9].

Relations with purchasers constitute an enterprise's strategic resource. Relationship and partnership marketing is becoming the key resource as far as the company's customers are concerned. It is understood as "profitable creating, maintaining and developing relations with consumers and other partners in achieving common goals by exchanging values and fulfilling obligations." The main focus is on the customer and not on marketing understood as one of the functions of the company. According to Rogoziński, relationship marketing stresses direct personal relations between the producer and their customer, as well as "soft" and more subtle methods of creating relations with customers, without depriving them of their right to autonomous choice [10].

The research conducted shows that only $25 \%$ of the enterprises surveyed manage relations with opinion-forming subjects in a regular way. One can also observe that subjects with which companies managed relations sporadically varied in importance. In this group, the most significant category was managing relations with competitors $(36,5 \%)$. It is also worth mentioning that the most popular answer was lack of any management of relations with opinion-forming subjects $(44,5 \%)$. The most frequently formed relations were the ones with purchasers, suppliers, employees and owners of the enterprise, whereas relations with opinion-forming subjects, competitors, local community and institutional environment were created only occasionally or are not created at all.

Another important aspect of the study is how the management of relations with the company's environment changes according to the development stage of the enterprise. Generally, companies at the stage of growth managed such relations more frequently than mature enterprises. Among 8 categories of relations, 4 were regularly managed rather by the companies at the growth stage, namely relations with purchasers, suppliers, opinion-forming subjects and employees. In the remaining 4 categories, that is relations with competitors, owners, local community and institutional environment, mature enterprises got a higher percentage for their regular management. On the whole, the most commonly 
managed relations were those with purchasers, suppliers, employees and owner, whereas the categories of relations which were not managed at all the most frequently were relations with opinion-forming subjects, competitors, local community and institutional environment. Interestingly, relations of all those 4 categories were not managed at all more frequently by the mature companies than by the enterprises at the growth stage. This may indicate that the latter are more aware of the need of relational resources management, as well as of the profits that it can bring to the company.

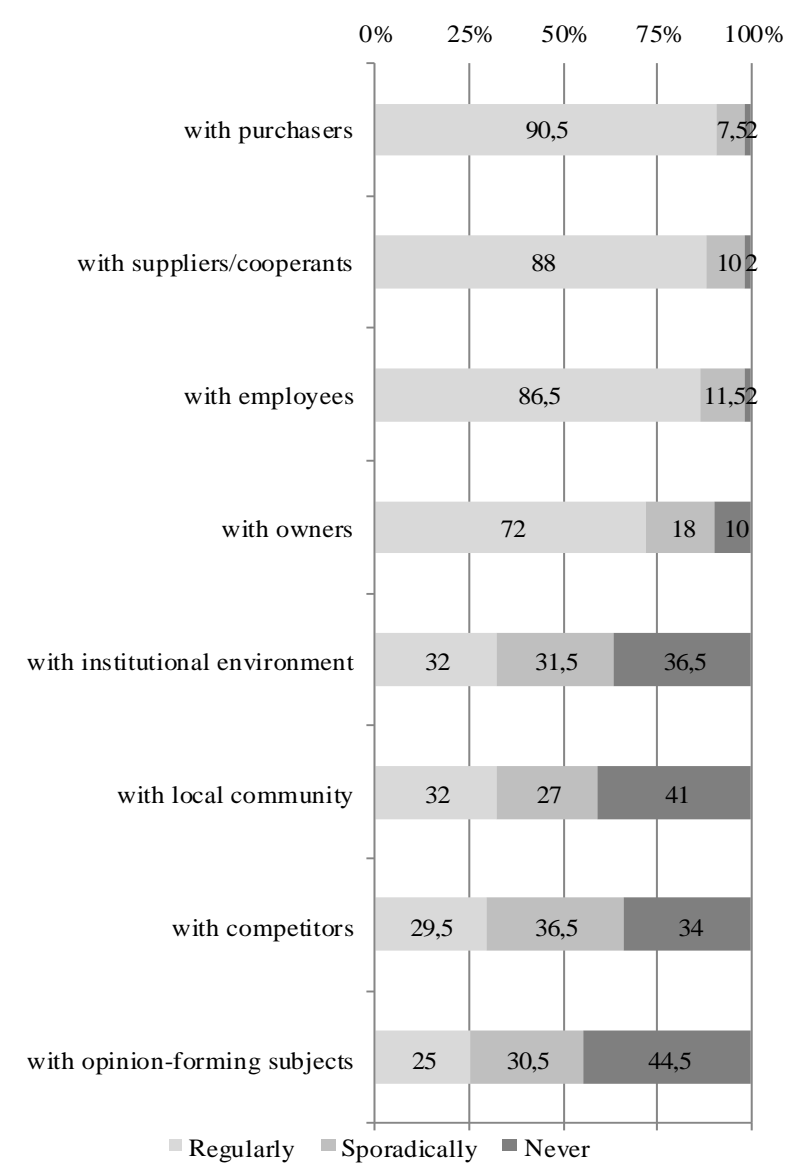

Fig. 1. Relations management in companies in the years 2009-2012 (\%).

TABLE I: RELATIONS MANAGEMENT IN COMPANIES IN THE YEARS 2009-2012 AND THE SCOPE OF THEIR ACTIVITY (\%)

\begin{tabular}{|c|c|c|c|}
\hline \multirow{2}{*}{$\begin{array}{l}\text { Factors } \\
\text { Relations management in } \\
\text { companies in the years } \\
2009-2012\end{array}$} & \multicolumn{3}{|c|}{ The company's scope of activity } \\
\hline & international & domestic & regional \\
\hline with purchasers & 90,2 & 93,5 & 76,0 \\
\hline with suppliers/cooperates & 82,4 & 91,9 & 80,0 \\
\hline with competitors & 35,3 & 25,8 & 36,0 \\
\hline with opinion-forming subjects & 31,4 & 22,6 & 24,0 \\
\hline with employees & 90,2 & 84,7 & 88,0 \\
\hline with owners & 86,3 & 65,3 & 76,0 \\
\hline with local community & 37,3 & 29,0 & 36,0 \\
\hline $\begin{array}{l}\text { with institutional } \\
\text { anviranment }\end{array}$ & 35,3 & 31,5 & 28,0 \\
\hline
\end{tabular}

The study shows that internationally operating enterprises got the highest percentage in five categories of relations (Table I), that is relations with employees $(90,2 \%)$, owners $(86,3 \%)$, local community $(37,3 \%)$, institutional environment $(35,3 \%)$ and opinion-forming subjects $(31,4 \%)$. Therefore, it can be stated that internationally operating companies show a higher level of awareness, as well as the need to manage relations with particular stakeholders in order to create competitive advantage and the enterprise's development.

What is more, the results demonstrate that the predominant relations established by the companies surveyed were the ones with purchasers and suppliers, whereas considerable potential lies in creating and developing relations with other subjects as well, especially with the local community or opinion-forming subjects. Management of relations with competitors got a rather small percentage of answers. A detailed analysis shows that many regionally operating companies declared that they did not build relations with competitors, opinion-forming subjects or the local community. Instead, they focused on establishing relations with the enterprise's employees, which is certainly positive. However, it may be surprising that regionally operating companies did not create relations with the local community which could help them establish competitive advantage. It should be noted that this results to a great extent from the enterprises' ignorance and the lack of their understanding of the necessity of such actions.

Another result was that companies with foreign capital were the ones which regularly managed relations of most categories. Enterprises with Polish capital led only in two categories - relations with purchasers and with suppliers/cooperate. As far as relations with competitors were concerned, most of the companies with foreign capital managed them regularly, whereas most of the companies with Polish capital did it sporadically. As for relations with the owners of the enterprise, regular cooperation was declared by more companies with foreign capital than with Polish one. Also, enterprises with foreign shareholders more frequently managed relations with the local community and the institutional environment. This represents the fact that such companies follow the example of countries in which the awareness of the role of creating relations in the enterprise's development is deep-rooted. They implement native strategies on the Polish market, taking into account the importance of the company's coexistence with the life of the local community, which helps the enterprise to develop.

The authors of the study assumed that relations marketing tools used by the companies were of considerable importance, so this category was analysed as the first one. The enterprises surveyed were asked which tools they used regularly, sporadically or never (Fig. 2). The study shows that most of the companies regularly used tools such as brand management $(65 \%)$, modern ways of distributing goods and services $(61,5 \%)$ and management of relations with customers $(49,5 \%)$. It is worth noting here that the least frequently used marketing tools were loyalty programmes (19\%) and packaging change $(12,5 \%)$. They were also the most popular in the category of the tools not used at all. On the basis of the obtained data it can be stated that marketing tools used regularly and those used sporadically are complementary.

It is interesting that the most popular marketing tool was 
the use of brand management. Among other company's assets, brand is distinctive probably because it can bring income to the enterprise in an independent way, and it can be separated from other assets. It is worth noting that the process of establishing the brand's value often takes many years, if not decades, and that the brand can lose its value much faster than traditional assets. Although it is difficult even to define a brand, and despite its non-material nature, it is one of the most significant sources of the company's value increase, thus being considered the key resource of the enterprise. From the point of view of the customer, brand is one of the most important factors taken into account when purchasing goods and services. From the point of view of the company, in turn, brand management and trademark creation are perceived as a guarantee of success and stability or increase of the enterprise's profits in the future.

It is worth noting that only less than $50 \%$ of the companies surveyed declared regular managing of relations with customers. This indicates a potential growth of this category which in turn could lead to reaching world level of using relations with purchasers to build and develop enterprises. Furthermore, the study shows that Public Relations activities were practised regularly by $47 \%$ of the companies surveyed and sporadically by $36 \%$ of them. It can be predicted that along with the growth of awareness of this category's significance enterprises will use Public Relations activities to create their image more frequently.

As far as special offers in points of sale and merchandising were concerned, $30 \%$ of the companies surveyed used these tools regularly, and $41 \%$ - sporadically. Promotional actions carried out in a skilful way constitute an important resource of the enterprise. Modern marketing is based on communication between producers and consumers, producers and middlemen (wholesalers and retailers), as well as between sellers and purchasers. The communication between the company and the market has a positive influence on market activities; it helps both sides (producer and consumer) to know more about each other and gain mutual trust. It also contributes to minimising the risk of producers, investors, distributors and consumers. Marketing communication makes prices more flexible, makes the use of resources more effective and its role continues to grow along with the increase of the competition.

The most significant aspect of the study was to analyse resources management taking into account the development stages of the companies surveyed. Firstly, author analysed the use of marketing tools. It turned out that they were regularly used mostly by companies at the growth stage. Mature companies, on the other hand, regularly used special offers in points of sale, merchandising and significant good or service modernising, whereas they only sporadically used the other tools (that is, majority of them). The only two tools used sporadically rather by companies at the growth stage than by the mature ones were good or service modernising and loyalty programmes.

Taking into consideration that today's economy is based on knowledge, looking for new solutions - as well as designing and implementing new competition rules - is becoming more and more important. This requires from enterprises to broaden their knowledge continuously and faster than their competitors. The new basis for market competition consists of unceasing reminding of the need to undertake new activities, defining their shape, creating new rules and standards of functioning, developing innovative attitudes and competences, as well as of continuous improvement of current activities. While analysing relational resources, it is worth noting that innovative abilities of the company play an important role in the question. The enterprise's resources increase along with the use of innovations in its development process. Innovations in the field of relational resources are, above all:

1) New marketing methods of products distribution consisting mainly in introducing new sales channels, that is methods used in order to sell products and services to customers, but not logistic methods such as transport, storage and trans-shipment. Examples of relational innovations in products distribution are: establishing and developing a franchise system, direct sales, exclusive retail sales or products licensing.

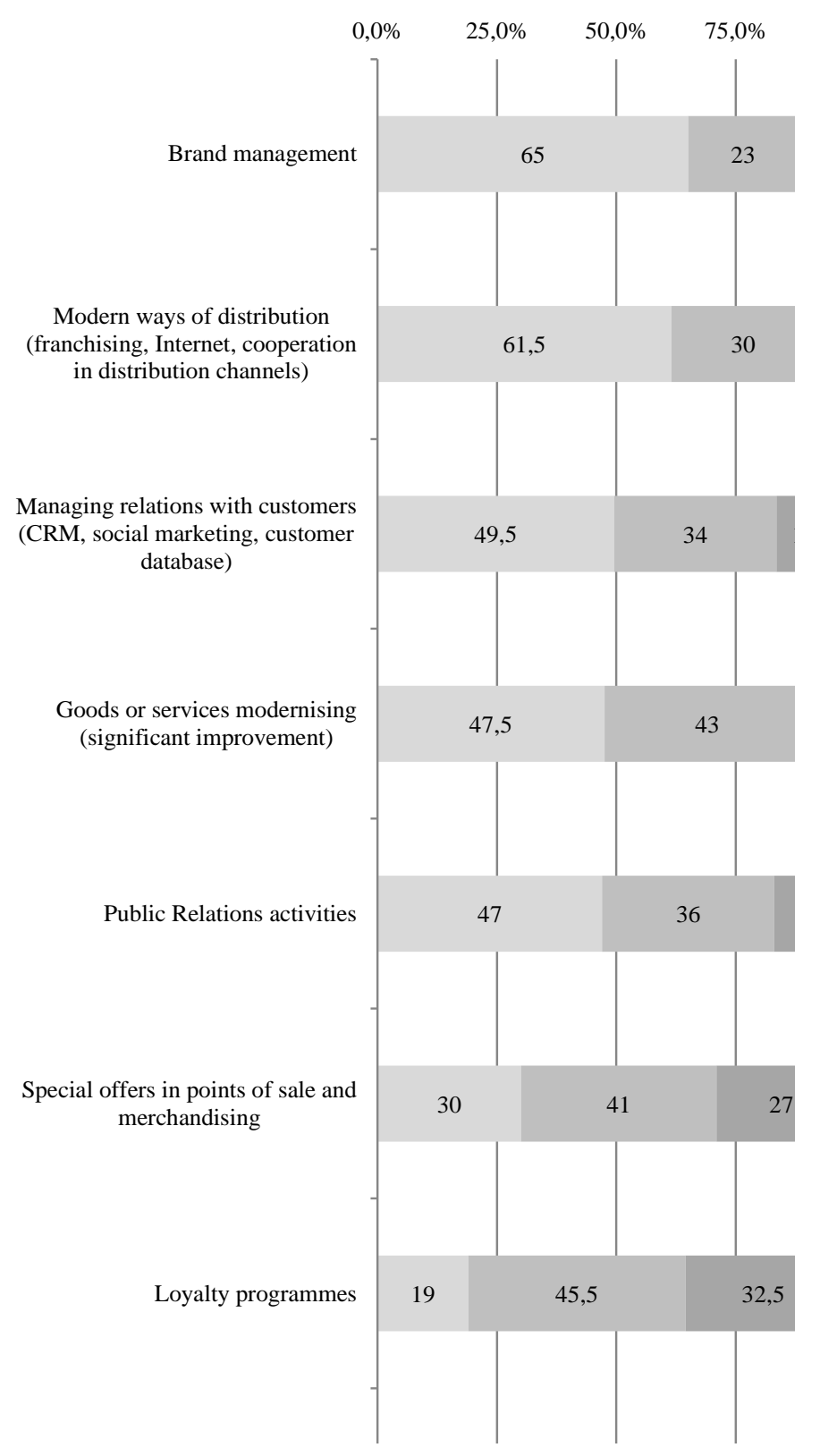

Fig. 2. Frequency of using relations management tools in companies (\%).

2) Introducing new pricing strategies in the sales of the enterprise's products or services. An example of this 
innovation may be a new method of price correction depending on the demand for a given product or service (e.g. when the demand is low, the price is also low). Another example is allowing customers to chose the desired features of a product on the company's website and then to check the price of the product with the chosen set of features. New methods of pricing whose only purpose is to diversify the prices forvarious segments of purchasers are not considered innovations.

3) New marketing methods of products or services promotion, for instance using considerably different carriers or media, such as product placement in films or television programmes, showing a well-known person as a user of a given product, as well as using new ways of products display, e.g. arranging furniture in a furniture store in a thematic way so that customers can see products in fully furnished interiors.

4) Considerable changes in products design or structure as an element of a new marketing concept, consisting in altering the shape or appearance of a given product without changing its functional characteristics. This can mean, for instance, a packaging change in products such as groceries and household detergents whose packaging is the main indicator of appearance. Another example is implementing significant changes to the form, appearance or taste of food and beverages, such as introducing new flavours to gain a new segment of customers.

5) Changes in a product's packaging, for instance introducing a completely new body lotion bottle in order to give it visual distinctiveness and attractiveness form the point of view of a new market segment.

In the empirical study conducted, one of several research problems was the domain of using modern solutions concerning relational resources (Fig. 3). Analysing the results of the study, it can be noted that most companies regularly used modern methods in the following areas: contacts with customers $(59,5 \%)$, products distribution or distribution channels $(54,5 \%)$, products or services pricing $(54 \%)$, products or services promotion techniques $(53 \%)$ and contacts with suppliers $(52,5 \%)$. The results show that no more than $60 \%$ of all enterprises regularly use modern solutions as far as relational resources are concerned. Taking into account that the study focused on companies with more than 50 employees, it seems surprising that almost $40 \%$ of them did not see the need to and, consequently, did not use innovative solutions in relational resources.

Furthermore, the authors of the study noticed other interrelationships within relational resource management (Fig. 4). Modern solutions were more frequently used regularly by enterprises at the stage of maturity (they led in 6 out of 8 categories of solutions) than by those at the stage of growth. On the other hand, companies at the growth stage led in 2 categories, namely the use of new media and of modern methods of contact with customers. In the years 2009-2012, they also introduced new marketing solutions (of 6 out of 8 categories) more often than the mature enterprises.

The mature companies led only in one category, namely the use of new media. The remaining one, that is significant changes in packaging design or structure, got the same percentage of answers from both types of enterprises. It is interesting to mention that this particular solution was not regularly used by any of the surveyed companies at the growth stage. On the whole, the most popular relational resources management solution, used regularly by $63,9 \%$ of the growing enterprises and by $56,4 \%$ of the mature ones was the use of modern methods of contact with customers. On the other hand, the least popular solutions were significant changes in product or packaging design or structure, which got from $0 \%$ to $26,5 \%$ of answers from the companies surveyed.

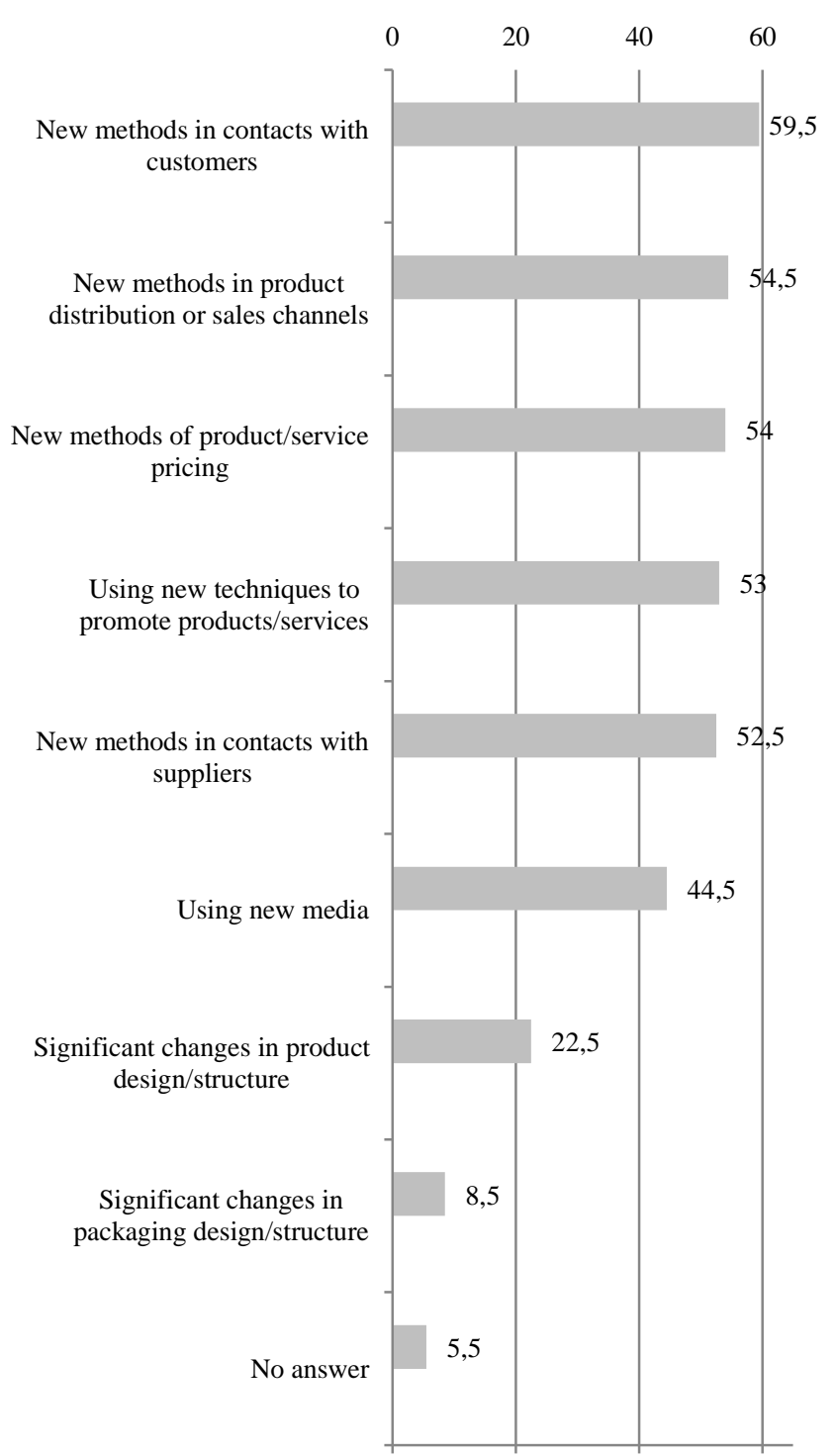

Fig. 3. Innovative solutions concerning relational resources used in companies $(\%)$.

Another interesting aspect is the relation between the companies' legal form and modern relational resources solutions used by them. Joint-stock companies were at the forefront of introducing new solutions in the years 2009-2012. It is worth noting that joint-stock companies' boards of directors have noticed the needs and possibilities of using the enterprise's relations with its environment to a greater extent than companies with other legal forms. 


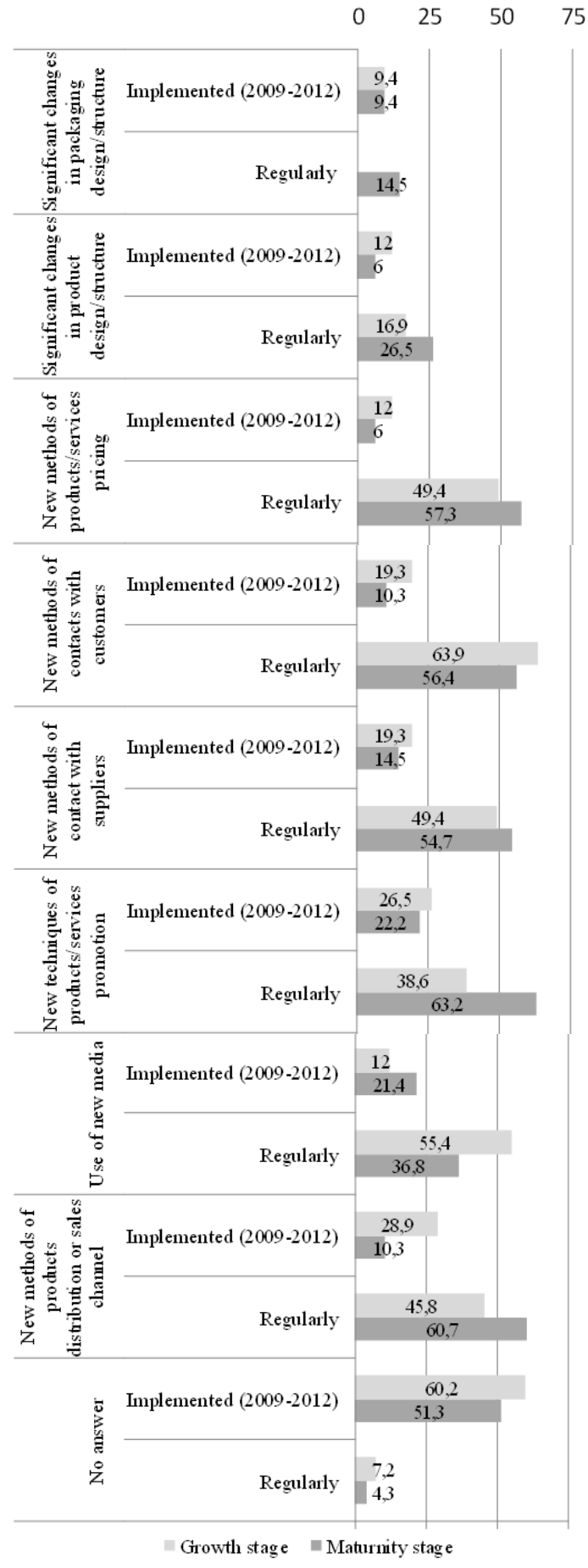

Fig. 4. Modern relational resources solutions and company's development stage (\%).

The analysis also shows that modern relational resources solutions were regularly used rather by medium companies than by big ones. Enterprises with more than 249 employees led only in the category of using new media. In other criteria, that are the company's domain of activity, scope of activity and proprietary capital, there were no statistically significant differences in the use of new solutions concerning relations creation.

Comparing the results of the study on Polish enterprises to West European trends, it can be concluded that Polish companies still have much to do concerning the use of appropriate marketing tools in order to create the enterprise's growth and development. The intensity and scope of the use of marketing tools by Polish companies differ from the developed countries' standards and practice. There exists large growth potential in this domain, which is significant from the point of view of the economic practice.

\section{MANAGERIAL IMPLICATIONS AND CONCLUSIONS}

It can be observed in today's economy that appropriate creation and use of relational resources are not sufficient for the company to become successful on the market. Therefore, there should be a broader approach to some resources in relations creation, which help enterprises to become more competitive. This approach should be oriented to all subjects which influence the company's functioning.

It is worth noting that the resource-based theory of enterprises highlights the importance of the company's inner values, and market success depends to a great extent on the key relational resources. These resources can also have negative value - a bad reputation or unfavourable connotations of the enterprise may have a negative impact on its strategy, as well as its development.

On the basis of the empirical study conducted and its results showed above, it can be stated that Polish companies regularly use relations management tools. This proves the research assumptions and hypotheses formulated in the introduction. Relations management tools are used by enterprises more and more frequently, and this use contributes to the development of innovativeness and to the creation of competitive advantage. What is more, there exist differences between companies at the growth and development stage, as far as the use of innovative relations management solutions are concerned.

The most popular regularly used tool was brand management, whereas the two most common sporadically used tools were loyalty programmes and packaging change. Research shows that enterprises in Poland regularly use relational resources solutions, above all new methods of contacts with customers and of products distribution and sales channels. The above-mentioned results show that Polish companies operate along with world trends and that the focus of their functioning is placed on the use of relational resources in creating competitive advantage.

The study also shows that enterprises with foreign capital and joint-stock companies use relations management tools more frequently than others. Medium enterprises regularly use marketing data analyses more often than big companies, and, generally, they collect data mostly on the customers' needs and preference. Another fact is that internationally operating enterprises manage their relations more frequently than other companies.

The study conducted proves that today in Poland there exists considerable potential of development and of the use of relational resources management to a greater extent than before. What is more, relational resources are the resource category that will attract more and more attention of companies looking for optimal solutions in order to use them to create innovations and the enterprise's development.

In conclusion, I contribute to the literature by 
demonstrating the usage of relational resources among companies and their influence on the development of the company. My examination of relational resources provides a strong foundation for subsequent research in these areas.

\section{REFERENCES}

[1] J. B. Barney, "Is the resource-based "view" a useful perspective for strategic management research? Yes," Academy of Management Review, vol. 26, issue 1, pp. 41-56, January 2001.

[2] J. H. Dyer and H. Singh, "The relational view: Cooperative strategy and sources of interorganizational competitive advantage," Academy of Management Review, vol. 23, pp. 660-679, October 1998.

[3] G. Ahuja, "Collaboration networks, structural holes, and innovation: A longitudinal study," Administrative Science Quarterly, vol. 45, pp. 425-455, September 2000.

[4] R. C. Sampson, "R\&D alliances and firm performance: The impact of technological diversity and alliance organization on innovation," Academy of Management Journal, vol. 50, issue 2, pp. 364-386, April 2007.

[5] P. Kotler, Marketing. Analiza, planowanie, wdrażanie i kontrola, Warsaw: Gebethner \& Ska, 1994, pp. 6.

[6] M. Bartnicki, Kompetencje przedsiębiorstwa. OD określenia kompetencji do zbudowania strategii. Miedzy nadzieja $i$ strachem. Budowanie mapy kompetencji, Warsaw: Placet, 2000, pp. 50.

[7] E. U. Sojkin, Ed. Podstawy wyborów strategicznych w przedsiębiorstwach, Warsaw: PWE, 2011, pp. 178.

[8] B. D. Korona, "Zarządzanie wartością klienta," Ekonomika $i$ Organizacja Przedsiębiorstwa, Instytut Organizacji, Zarządzania w Przemyśle Orgmasz, vol. 2, pp. 21, 2002.
[9] P. Kotler, G. Armstrong, J. Saunders, and V. Wong, Marketing. Podręcznik europejski, Warsaw: PWE, 2002, pp. 20.

[10] K. Rogoziński, "Marketingowy przełom," in Marketing 2001, vol. 1, W. Gaworecki, J. Senyszyn, and M. Daszkowska, Eds., Sopot: Uniwersytet Gdański, 1998, pp. 274-282.

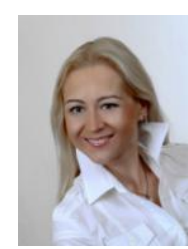

Marta Ziólkowska was born in Warsaw (Poland) at February, 11 1979. Her educational background is MA in management and marketing, Warsaw School of Economics, Poland, 2003 and Ph.D. in management, Warsaw School of Economics, 2009. Her work experience is assistance professor at Institute of Management at Warsaw School of Economics in Warsaw, Poland. Junior researcher at Victoria University of Wellington (New Zealand). Visiting professor at University of Porto (Portugal) and Zagreb School of Economics and Management (Croatia). Business consultant in franchising systems among SME's in Poland. She also takes part in EU project concerning conducting lectures in virtual world - "Second Life". She published in Poland following books about the franchising networks, modern cooperation business models and management - Franczyza nowoczesny model rozwoju biznesu (Warsaw, Poland, CeDeWu, 2010), Nowoczesne modele współpracy przedsiębiorstw (Warsaw, Poland, CeDeWu, 2013), Management essentials, Practice textbook for students (Warsaw, Warsaw School of Economics Publishing House, forthcoming). Her research interests cover fields like: entrepreneurship, innovations in organizations, SME management, social media and franchising. Marta Ziółkowska is a member of MAG Scholar Marketing in Asia Group and Vice President of Enrolment Committee to Second-Degree Studies at Warsaw School of Economics. 